\title{
13
}

\section{THE MEDICAL PROBLEMS OF OPERATIONS IN THE HILLS}

\author{
Tony White and Ian McDougall
}

\section{Introduction by Ron Boxall}

The aesthete Morihei Ueshiba, a veteran of the Russo-Japanese war of 1904-05 and who later became famous as an enlightened martial artist, once said, 'Loyalty and devotion lead to bravery. Bravery leads to the spirit of self-sacrifice. The spirit of self-sacrifice creates trust in the power of brotherly love'. ${ }^{1}$ No more needs to be said to introduce a chapter which showcases men who were routinely called upon to put the welfare of mates before all else - the reader will find threads of Morihei's sentiments as a recurring theme among the following paragraphs, and in other parts of this book.

\section{Tony White}

By October 1966 - after five months in Vietnam - the battalion's physical and mental health was at its peak. The soldiers were now well acclimatised. The wet season, with its endless mud, mould and misery, was over. The incidence of fever and skin disease and the rates of non-casualty hospital admissions had fallen. Hygiene practices, including malaria prophylaxis,

1 Morihei Ueshiba, Meditation and the martial arts, Shambhala Publications, Colorado, US, 2005, p 67. 
were accepted and practised. Conditions back in the battalion lines at Nui Dat were more comfortable with amenities such as company canteens, the outdoor cinema and the Task Force concert area (the 'Dust Bowl') providing welcome distractions from relentless duty. The troops were getting used to the rhythm of one or two weeks out on operations followed by a week or two of physically demanding base development tasks and defensive patrolling. During their 12-month tour of duty, they were able to look forward to a two-day break of rest and convalescence on the beach at Vung Tau as well as one spell of five days rest and recreation elsewhere in Asia.

Medical cover for the battalion was provided by the Medical Platoon. This comprised the regimental medical officer (RMO), two staff sergeants (Mick Seats (medical) and Ayb Brown (hygiene inspector)), five corporal medical assistants (trained to basic nursing level) and the stretcher bearer/ bandsmen. The RMO, staff sergeants and one corporal constituted the regimental aid post (the medical centre) at Battalion Headquarters (BHQ) when in the base area. The other corporals were distributed one for each of the four rifle companies, taking care of day-to-day medical problems. By this stage of the year, medical personnel at every level were becoming more confident in handling both casualties and sickness. Pharmaceutical resupply when out on operations was working well, ably handled by Mick Seats who remained in the regimental aid post at our Nui Dat base. Above all - for both the troops and their medical attendants - was the peace of mind from having a superb and timely helicopter aeromedical evacuation Dustoff system. This could enable casualties to be in hospital care within an hour of an incident, service far superior to what was available for the general population in Australia at the time.

By any measure, I was grossly under-prepared for the role of RMO of an infantry battalion on active service. At the age of 25 , I had only just completed my intern year, where my surgical experience had been limited to suturing drunks in the Emergency Department and to serving as a very junior assistant in surgical operations at Sydney Hospital. I had no first aid training. A teaching hospital is no place to learn the bread-and-butter medicine that constitutes the bulk of an RMO's work; such experience is gained over a couple of years in a general practice setting. My knowledge of tropical medicine was a textbook on the subject plus a hazy recollection of one term's lectures during the medical course at Sydney University. My posting to the battalion was as a rushed, last-minute replacement, two months before our deployment to Vietnam. This meant that I was 
plucked out of the six-week Indoctrination Course at the School of Army Health at Week 2. The course was designed to ease the transition of young civilian doctors into the army system. Here one was taught not only aspects of military medicine, kit, uniforms and the rank structure, but also basic tactics, living in the bush, handling of weapons and so on. Missing out on this part of my education was a major handicap. I had been in my school Sea Cadets in Kenya and a pilot officer in the Cambridge University Air Squadron, but there were huge gaps in my knowledge of the military culture at the time I joined the battalion. For example, I was unsure whether it was I who was to salute the regimental sergeant major or the other way around. Fortunately, I was generously supported by my fellow officers throughout.

The life of a battalion RMO on active service is one of unremitting humdrum toil punctuated by episodes of intense, sometimes extremely stressful, activity. But I was never idle. When in the Nui Dat base area between battalion operations, the day began with a sick parade which could last all morning. The most common disorder seen was skin disease, particularly fungal and bacterial infections. This was not surprising considering the relentless heat and humidity, friction from clothing and webbing equipment, and minor cuts and scratches. The troops often went days without an opportunity for showering and a change of clothes. Other common conditions included respiratory infections, orthopaedic problems (knees, backs, ankles), sexually transmitted diseases and fevers. Malaria was held in check by rigorous application of preventive measures.

My other routine duties in the base area included inspections of the battalion area with the hygiene staff sergeant. Attention to proper standards of food-handling, garbage disposal, latrines and so on may sound unglamorous but, if neglected, has often resulted in outbreaks of disease which can impact more on manpower than battle casualties. Other duties included reporting on the health situation in the battalion and among the civilians attending village clinics. There were debriefing and training sessions with medical assistants and stretcher bearers, discussions with the commanding officer and company commanders and - transport permitting - trips to the hospitals in Vung Tau to visit battalion members and liaise with the doctors. As RMO, I understood the importance of getting out of the regimental aid post as much as possible and taking every opportunity to visit companies to discuss medical problems, debrief 
after incidents and get to know - and be known by - the soldiers. A large commitment of time and effort was the Medical Civic Action Program in which I ran clinics for civilians in neighbouring villages.

This relatively routine schedule back in the base area could be shattered on occasion, calling for an adrenaline-filled sprint. One such instance was early one morning when two grenades were accidentally discarded into a pit in which a fire was burning. There was an impressively loud explosion but fortunately the injuries to bystanders were slight. At the other extreme was a horrific accidental shooting. I was engaged in paperwork at the regimental aid post one afternoon when I was summoned by an out-ofbreath runner. I ran flat out up to a tent in B Company lines to find a soldier with a massive gaping wound in his chest. He was beyond help. Close by on the floor lay his mate, pounding the ground with his fist and howling with grief. They had been handling a non-issue shotgun when it discharged, with a disastrous consequence. The two were close friends and the dead soldier had been the other's best man at his wedding before they embarked for Vietnam. On return to Australia the dead man was to have married his mate's sister-in-law. There was a sequel to compound this tragic event. Three months later, the survivor of the shooting was himself to lose his life when the patrol of armoured personnel carriers in which he was travelling ran into a minefield. Six other soldiers were also killed and 27 wounded. Two of these - the company commander and platoon commander - were to die of their wounds over the following week. It was an utterly harrowing scene, with the casualties spread over an area the size of a tennis court. Assisted by the one surviving medic - himself wounded - I found myself almost overwhelmed by the needs of the casualties and their sheer number. Of course, the knowledge that we were walking and working in a minefield made for an hour of terror pending the arrival of Dustoff casualty evacuation helicopters and sappers to clear the remaining mines. This catastrophe - the biggest minefield incident in Australia's involvement in the Vietnam war - was certainly the worst incident of my army service. I found all encounters with casualties extremely distressing. A summons to 'fetch Starlight' (the radio call sign of the RMO and medics) would fill me with dread. There was no knowing what lay in wait except the certainty that it would be awful. 
In any discussion of the Medical Platoon, the Battalion Band merits special mention. Numbering 25 and under the command of bandmaster Warrant Officer Bob Taylor, they were a disparate group. Eight had served an apprenticeship at the army School of Music; others had musical experience at school, church or in community bands. Their instruments were cornets, horns, trombone, euphonium, tuba, saxophone and percussion. When not out on operations the band was in constant demand, playing at ceremonial parades, church services, memorials, hospitals and, on visits to villages, as part of the civic action program.

As well as their infantry and musical duties, bandsmen also had basic first aid training to provide care for casualties when out on operations. Allocated one per platoon (30 men), they were officially known as stretcher bearers, a hangover from the 19th century when the retrieval of casualties from the battlefield was becoming formalised. At that time any non-combatant, including bandsmen, would be mustered to the task of clearing the dead and wounded from the battlefield.

The practice was taken up by the fledgling Australian Commonwealth Military Force and a General Order in 1902 ordained that 'all bandsmen, in addition to their duties as such, should be trained as stretcher bearers and should be allocated to companies in time of war'.

In past wars - and even to some extent within the battalion in the early days - there was an initial widespread belief that bandsmen/stretcher bearers were shirkers, not real soldiers. The fact that they were musicians may have further contributed to this attitude. Such disdain was soon banished once their dedication and courage became common knowledge. They were fully armed to protect themselves and the casualties in their care. During our year of service in Vietnam, two of the battalion's stretcher bearers received bravery awards, one was killed and four were wounded. In the trying conditions of the October 1966 operations in the hills they again acquitted themselves with honour.

The skills of the medical assistants and stretcher bearers were soon to be put to work. It was on Day 3 of Operation Canberra that two platoons were hit in separate booby trap incidents, wounding eleven soldiers, three of them seriously. First aid was administered and helicopter evacuation effected after a minimal landing zone had been cleared. One disappointing defect in the medical system was that first responders did not receive any 
follow-up on the casualties they had cared for until the RMO, in the days or weeks ahead, was able to find an opportunity to visit the hospitals to which they had been evacuated.

The five-day road-holding task (Operation Robin) that immediately followed Operation Canberra was an opportunity to carry out Medical Civic Action Program clinics (MEDCAPs) at villages on Route 15 along which the battalion was strung. MEDCAPs were staged during operations whenever time and the tactical situation permitted. The team consisted of the RMO, a Royal Australian Army Medical Corps (RAAMC) noncommissioned officer, one or two stretcher bearers and an Army of the Republic of Vietnam interpreter. Clinics were conducted in any suitable building or under a marquee. In wartime Vietnam, the civilian population had very limited access to medical care. Road travel to clinics and hospitals was perilous. The last time the inhabitants of Long Cat village had seen a doctor was three years previously, when an American army unit had passed through. Consequently, MEDCAPs were invariably extremely popular with villagers. Sometimes as many as 75 patients would be seen in three hours.

If the situation was suitable the bandmaster assembled the stretcher bearer/bandsmen and arranged for their instruments to be brought out by truck from Nui Dat. A brass band concert - a rare experience for the locals - ensued, greatly lightening the atmosphere.

The MEDCAPs had immense public relations value and were recognised as a useful contribution to counter-insurgency. For the battalion medics, they provided welcome contact with Vietnamese civilians and an understanding of their health problems. However, their medical utility was extremely limited. The main problems were the language barrier even with interpreters - and the lack of privacy to permit an effective physical examination. These factors, as well as a total absence of laboratory help, rendered accurate diagnosis almost impossible. When a confident diagnosis could be made, the range of medications available for their treatment was limited. Above all was the huge burden of chronic disease malaria, tuberculosis and hookworm - prevalent in the population. These diseases require long-term treatment under close supervision; a flying visit by a well-intentioned team was utterly ineffective and could only engender false hope. 
Even though the MEDCAPs could be tiring, I always found them interesting and the civilian contact a lively counterpoint to military life. Sometimes this could be a challenge. The priest at Long Cat village kindly invited me to lunch. The main dish was smashed duck in a bowl of blood with spicules of bone for consistency. Not wishing to offend, I managed to get through it with the aid of rice whisky which was somewhat redolent of aviation gasoline.

One afternoon I was standing at the roadside at the C Company position, having done a 'house call' and awaiting a ride with the Sioux reconnaissance helicopter to take me back to BHQ. The chopper sped towards us, flying just a metre above the road surface, when it suddenly hit the ground, cartwheeling down the bitumen, pieces of the aircraft flying off, until the shattered wreck came to rest metres from where we were standing. The pilot, Second Lieutenant Bill Davies, had a head injury and was unconscious. We stunned onlookers had no idea as to what had caused the crash, although the possibility of sniper fire was raised. His passenger was Staff Sergeant 'Sailor' Mealing, a Korean War veteran and colourful battalion identity. He had several fractures and his evacuation to hospital in Vung Tau was expedited. Because of Davies' head injury, I decided to call for a second Dustoff helicopter and escorted him to a hospital with neurosurgical facilities in Saigon. Both casualties survived and were evacuated to Australia in the weeks ahead. Bill Davies relates the story of his crash and his evacuation and recovery in Chapter 14.

Leaving the roadside for the second excursion into the hills (Operation Queanbeyan) meant a return to the toughest terrain most of us had ever encountered. The going was steep with an average gradient of 1 in 3, on a track slippery from the tail end of the wet season. The troops were carrying kit, ammunition and rations totalling some 30 kilograms. The hillside was littered with giant granite boulders, some as big as shipping containers, riven by clefts and caves, and overlain with tall trees and dense undergrowth, perfect for snipers. This setting and our awareness of the presence of the enemy and booby traps along the track raised the level of tension considerably.

On the morning of the first day of Operation Queanbeyan (17 October), four soldiers of A Company were wounded by one such booby trap. That same afternoon the Reconnaissance Group, 100 metres or so uphill from where BHQ had paused, had come under fire and its leader, Captain Brian Le Dan, was reported as wounded. I took off up the track to join 
him. He was a lucky man: the bullet had struck his Owen gun and he received only a flesh wound on the chest wall from fragments. Bleeding was readily controlled with a shell dressing. We settled down in the shelter of a large rock until he felt confident enough to walk back down the track with me to where it was possible for him to be extracted in a remarkable piece of helicopter piloting (Chapter 14) and conveyed to hospital. Shortly afterwards, Corporal Norm Womal was shot leading his section to clear the area. He lay in a very exposed position. In the time-honoured tradition, stretcher bearer Private Peter Fraser - against orders - crawled forward under fire, dressed the wound, shielded Womal from enemy fire and assisted a carrying party to bring him to me further down the slope. Womal had a bullet entry wound above the collarbone and it was obvious that he was bleeding freely from a major vessel within the chest. There was no way to stop the bleeding. The small amount of albumin that I was carrying and administered intravenously could not keep pace with his blood loss and he died within 20 minutes. (Details of this engagement are described in Chapter 7.)

The next two days were taken up with assaults on caves along the track. These actions were costly, with the death of Private Gordon D'Antoine on 18 October and the serious wounding of two soldiers by a booby trap grenade the following day (Chapter 7). One of the wounded was Private Trevor Lynch. Non-medical people often think that medics are quite unfeeling and able to go about their duties focusing only on the technical task that lies before them. Corporal Ian McDougall RAAMC was attached to the Pioneer Platoon that afternoon and had to deal with the two casualties. Ian was the only national service corporal in the Medical Platoon. His account gives some insight into the toll that casualty management can impose on those charged with tending to those in their care.

\section{Ian McDougall}

Trevor Lynch and another soldier had been detailed to make the actual assault with the backpack flame-throwers. We did not see their initial approach, but suddenly there was the almighty crack of a mine detonation, followed by loud screaming. With clearance from the section commander I was with, I made my way back to the track and down then out to where the wounded lay. 
To say I was scared stiff would be a gross understatement. The two men lay immediately in front of the caves which had numerous entrances with little cover. I recall feeling very lonely and totally exposed.

I turned my attention to Trevor, who was screaming in a demented fashion and writhing on the ground. He had sustained multiple wounds; in fact, his was the most mutilated human body I had ever seen and ever want to. I had great difficulty deciding where to start as he had dozens of bleeding wounds, some of them very serious, broken limbs and many facial injuries. The front of his body was a mass of puncture wounds. I remember, as I started applying wound dressings, that I had to tie Trevor's hands together to stop him dislodging dressings and doing himself more damage. I recall that I was crying at one point due to the frustration I felt in trying stop blood loss from so many wounds at once. I doubt if Trevor was aware at that time of anything, and his wild screaming continued unabated, but I do recall that Captain Tony White, the 5 RAR RMO, joined me at some stage. I have tried hard since to forget that incident, and have obviously partially succeeded, as I do not recall how or when my patient was evacuated, or what happened to the other soldier or even if I had treated him.

\section{Tony White}

Trevor Lynch survived but was totally and permanently incapacitated, losing both eyes and being confined to a wheelchair until his early death at the age of 51. Ian McDougall, despite being plagued by post-traumatic stress disorder, went on to have a successful career in the Australian Federal Police. No medic can erase the memory of the maimed soldiers for whom he did his best and that memory is rendered more painful by the flood of emotions that accompanies it.

The Nui Thi Vai hills operations were an intense, physically and mentally demanding 20 days of almost continuous and varied activity. Aside from the steady stream of medical problems - bronchitis, twisted knees, sprained ankles, crotch rot and so on - there were the fearful and intensely stressful battle casualties with which to contend. I am proud of all in the Medical Platoon who acquitted themselves so well in such trying circumstances. 


\section{Editors' conclusion}

At war, all infantrymen are continuously mindful of the inescapable likelihood of casualties. How well they function effectively for extended periods depends on an individual's confidence in himself, his training, the systems within which he operates and others who support him. Much of this confidence emanates from a sense of being part of the hierarchical entity which includes his platoon, his company and his battalion. This cossets him in a brotherhood of identity, acceptance, obligation, shared danger, mutual dependence and pride. Deep interpersonal bonds which become unshakeable lifelong friendships are inevitable. To Australians the phenomenon is just 'mateship' - long held to be among the foremost of our distinctive national traits.

Much is written of such things; often without good, firsthand examples of the many factors which are at play in moulding the resilience of those whose duty is to seek out and destroy an enemy. The words of Tony White and Ian McDougall give a hint of the many facets of an infantry battalion at war which are sparsely aired in most postwar accounts. Notably, they vividly impart the morale effects of having members of our battalion's dedicated medical team, including our RMO, deployed at the forefront of danger.

The impact of rapid aeromedical evacuation of casualties to sophisticated surgical facilities during the Vietnam War has deservedly been hailed for its effects on survivability and morale. But the comfort of having, right at hand, known mates who were trained to be casualty first responders was a pearl beyond price.

Our medical team, in providing that response on the battlefield, first had to reach the soldiers who had been wounded, lying immobile on the ground, often still under direct enemy observation. As they moved forward to help those in need, they had to make hard choices on whom to treat first. They had to shed normal concerns for their own safety and frequently accept a very high degree of personal risk over short periods. We never saw any of our Medical Platoon members hesitate as they entered a danger zone. Such areas were particularly threatening when they included hidden mines and booby traps, activated by barely visible tripwires, concealed pressure switches or remote-control wires laid underground and reaching back to a control point where the firer could lie, hidden from view and in 
relative safety. They entered and moved about areas where mines or booby traps had been encountered, or where the enemy was in close proximity, to treat first those wounded whom they judged to be in greatest need.

A second difficult scenario that our medics had to face was the constant pressure to give effective assistance to the people in the villages through which we had to operate, and with whom we wanted to develop good relations. The locals trusted us, and that made our awareness of the limited nature of the medical assistance that we could provide particularly worrisome. This awareness arose first and foremost in the minds of our medical team, who could see the consequences of being able to provide only very limited assistance more clearly than any of us.

Many share the view that our medical team's devotion to our casualties, with the special risks that such devotion entailed, was worthy of very high recognition. Similarly, their vital role in helping us gain the trust and confidence of local villagers merited special mention. Our confidence in their bravery, knowledge and compassion made a huge difference to our battalion's effectiveness in counter-insurgency operations. 
This text is taken from Vietnam Vanguard: The 5th Battalion's Approach to Counter-Insurgency, 1966, edited by Ron Boxall and Robert O'Neill, published 2020 by ANU Press, The Australian National University, Canberra, Australia.

doi.org/10.22459/VV.2019.13 